\title{
ABIO: Associação para o Estudo do Biodireito
}

Rui Ramalhal ${ }^{1}$

Autor Correspondente: Rui Ramalhal [rui.ramalhal@jmellosaude.pt]

PALAVRAS-CHAVE: Bioética; Direitos Humanos

KEYWORDS: Bioethics; Human Rights

A evolução da ciência e os progressos tecnológicos no âmbito da Biologia e da Medicina há muito que suscitam interrogações de ordem ética e deontológica. A consciência da necessidade de definir limites a experiências e práticas que pudessem colidir com a própria dignidade da pessoa levou ao surgimento da Bioética.

Assim, em meados dos anos 70 do século passado, foi criado no Congresso Norte-Americano uma Comissão com o objetivo de identificar os princípios básicos que deveriam nortear a experimentação em seres humanos nas ciências do comportamento e na Biomedicina. Em 1978 foi aprovado o resultado dos trabalhos desenvolvidos por essa Comissão, no que ficou conhecido pelo "Relatório de Belmont". Este relatório identificou aqueles que passaram a ser reconhecidos como os princípios gerais da Bioética: o respeito pela autonomia, a beneficência e a justiça, tendo no ano seguinte sido autonomizado o quarto princípio da não-maleficência.

O respeito pela autonomia traduz o reconhecimento da capacidade de decisão e liberdade de escolha do indivíduo, necessariamente fundadas no conhecimento da sua situação e dos benefícios e malefícios dos procedimentos em causa. Este princípio vem, designadamente, alterar o entendimento paternalista da relação médico-doente e tem como corolário a obrigatoriedade do consentimento informado do doente para a realização de um conjunto alargado de atos médicos.

O princípio da beneficência evidencia o objetivo último das ciências da saúde de procurar alcançar o bem-estar do doente utilizando os melhores meios (legis artis) ao dispor, sempre na perspetiva do interesse do doente. Daqui decorre, entre outros, a ilegitimidade da designada obstinação terapêutica por, em última análise, não ser benéfica para o doente.

O princípio da não-maleficência decorre e complementa o anterior, determinando a obrigação de não infligir intencionalmente danos ao indivíduo.

Por último, o princípio da justiça visa a distribuição dos recursos de saúde disponíveis de acordo com critérios de equidade e imparcialidade, situação tanto mais difícil de gerir quanto maior a escassez de meios. 
Em paralelo com o desenvolvimento da Bioética foi-se tornando manifesta a necessidade de regular os avanços da investigação e o progresso tecnológico nas ciências da saúde, por forma a garantir a aplicação prática de determinados princípios éticos e o respeito pela autonomia e a dignidade da pessoa. É com este propósito e enquadramento que se tem vindo a autonomizar um novo ramo do ordenamento jurídico que podemos designar como Biodireito.

Uma das principais fontes do Biodireito, que contribuiu decisivamente para o seu desenvolvimento, é a "Convenção para a Proteção dos Direitos do Homem e da Dignidade do Ser Humano face às aplicações da Biologia e da Medicina" (Convenção sobre os Direitos do Homem e da Biomedicina), igualmente conhecida por Convenção de Oviedo, aberta para assinatura em 4 de abril de $1997 .^{2}$ Entre diversos preceitos orientados para a defesa e proteção da dignidade do ser humano, prevê no seu artigo $2^{\circ}$ que "o interesse e o bem-estar do ser humano devem prevalecer sobre o interesse único da sociedade ou da ciência", o que poderá ser considerado como um dos princípios basilares da regulação jurídica no que a esta matéria concerne.

Pode-se, pois, definir o Biodireito como o complexo de normas jurídicas que visam regular a experimentação científica e o desenvolvimento tecnológico nas áreas da Biologia e da Medicina, designadamente ao nível de novas terapêuticas, por forma a garantir que estas atividades não violam princípios éticos fundamentais que decorrem da própria natureza e dignidade do ser humano.

Sendo o respeito pela dignidade e bem-estar da pessoa um dos valores básicos do Grupo José de Mello Saúde, expressamente consagrado no seu Código de Ética, existe de há muito uma especial atenção aos temas da Bioética e, numa perspetiva jurídica, ao Biodireito.

É neste contexto que foi recentemente constituída, entre a José de Mello Saúde e a Faculdade de Direito da Universidade Nova de Lisboa, a ABIO - Associação para o Estudo do Biodireito.

A ABIO nasce no seio de um consórcio entre a José de Mello Saúde e a Universidade Nova de Lisboa denominado TAGUS TANK (Tagus Academic Network for Knowledge), sendo uma associação sem fins lucrativos que irá dedicar-se à investigação, ao ensino e à divulgação do Biodireito através, designadamente, de ações de formação, publicação de textos científicos e a organização de colóquios e conferências.

Após uma primeira fase de instalação e marcando o início da sua atividade, a ABIO irá organizar no dia 2 de novembro de 2016, na Reitoria da Universidade Nova de Lisboa, a sua primeira Conferência dedicada ao tema "Acesso à Inovação em Saúde".

Esta conferência contará com as intervenções do Professor Doutor Pedro Pita Barros, professor catedrático de economia e especialista em economia da saúde, do
Professor Doutor Dirk Arnold, professor catedrático de ciências médicas e médico oncologista, e da Professora Doutora Helena Pereira de Melo, professora catedrática de direito e especialista em direito da saúde e Biodireito. Estarão assim reunidos para debater o referido tema, especialistas das principais áreas do saber que concorrem para a sua análise e, idealmente, apresentação de propostas de solução para os problemas que o mesmo coloca.

O tema "Acesso à Inovação em Saúde" é de uma enorme atualidade. Como acima referido, o princípio bioético da justiça visa a distribuição dos recursos de saúde disponíveis de acordo com critérios de equidade e imparcialidade. A aplicação prática deste princípio implica, necessariamente, a garantia da sustentabilidade financeira do sistema de saúde sem a qual não haverá condições de proporcionar sequer os cuidados básicos de saúde às populações mais carenciadas que deles necessitam.

Com a grave crise financeira que assolou o mundo e o país, e que parece longe de estar resolvida, o aumento da esperança de vida e a quebra de natalidade sentida nos últimos anos, a questão da sustentabilidade do sistema de saúde coloca-se em Portugal com enorme premência. É neste quadro que o acesso a novas terapêuticas com custos elevadíssimos para o Serviço Nacional de Saúde suscita questões que são do foro ético e que, igualmente, desafiam o ordenamento jurídico. É ou não eticamente aceitável ou exigível o Estado despender centenas de milhares de euros para tratar um ou um grupo reduzido de indivíduos? Sendo os recursos escassos e não sendo possível acorrer a todas as necessidades, quais os critérios para escolher um ou outro doente como beneficiário de uma nova terapêutica de custo elevado?

Trata-se, no fundo, da velha temática dos critérios de utilização e afetação de recurso escassos sempre presente em cada exercício orçamental, no Estado, nas empresas ou nas famílias, mas que, quando envolve valores como a vida humana, assume uma relevância extraordinária e suscita discussões necessariamente influenciadas por aspetos emocionais.

Esperamos com a atividade a desenvolver pela ABIO contribuir, pelo menos, para suscitar o debate e esclarecimento de algumas destas questões na sociedade portuguesa.

CONFLITOS DE INTERESSE: Os autores declaram a inexistência de conflitos de interesse na realização do trabalho.

FONTES DE FINANCIAMENTO: Não existiram fontes externas de financiamento para a realização deste artigo.

\section{REFERÊNCIAS}

1. Department of Health, Education, and Welfare; National Commission for the Protection of Human Subjects of Biomedical and Behavioral Research. The Belmont Report. Ethical principles and guidelines for the protection of human subjects of research. J Am Coll Dent. 2014;81:4-13.

2. Council of Europe. Convention for Protection of Human Rights and Dignity of the Human Being with Regard to the Application of Biology and Biomedicine: Convention of Human Rights and Biomedicine. Kennedy Inst Ethics J. 1997:7:277-90. 